\title{
Treatment of Sacroiliac Fractures-Disjunctions by Percutaneous Screwing (About 10 Cases)
}

\author{
El Ghadraoui R*, Bensassi A, Maanouk R, Abid H, El Idrissi M, EL Ibarhimi A, El Mrini A
}

Orthopedic and trauma B4 Service, CHU Hassan II de Fès, Morocco

DOI: $10.36347 /$ sasjs.2020.v06i10.009

| Received: 07.10.2020 | Accepted: 20.10.2020 | Published: 30.10 .2020

*Corresponding author: EL GHADRAOUI Redouane

\section{Abstract}

Original Research Article

This is a retrospective study of ten patients admitted for a sacroiliac disjunction fracture treated with percutaneous sacroiliac screwing at the Trauma-Orthopedics B4 Department of Hassan II University Hospital in Fez. These are young patients who have been the victim of high kinetic energy accidents and admitted in a context of polytrauma. The standard pelvic X-ray allowed the diagnosis; it was supplemented by CT for exploration of posterior lesions based on Tile's classification modified by the OA. Postoperatively, early passive rehabilitation was prescribed for our patients, support was not authorized before 03 months with satisfactory radioclinical results for all of our patients. The interest of our study is to show the importance of this surgical technique, which has been well described in the literature with in particular a marked reduction in blood loss and the risk of infection.

Keywords: sacroiliac, pelvis, percutaneous screwing.

Copyright $(\mathcal{C} 2020$ The Author(s): This is an open-access article distributed under the terms of the Creative Commons Attribution 4.0 International License (CC BY-NC 4.0) which permits unrestricted use, distribution, and reproduction in any medium for non-commercial use provided the original author and source are credited.

\section{INTRODUCTION}

Sacroiliac disjunctions are rare lesions associated with a limited initial vital prognosis due to the severity of the associated vasculo-nervous and pelvic-perineal lesions.

In 1993 Chip Routt et al. reported the percutaneous sacroiliac screw technique based on the use of fluoroscopy, this fixation is now one more method in the therapeutic arsenal of pelvic ring trauma surgery [1].

\section{MATERIALS AND METHODS}

We report here a retrospective series of ten patients treated and operated by percutaneous sacroiliac screwing in the Hassan II University Hospital in Fez. These are young patients who were victims of a high kinetic energy accident. All of our patients underwent a standard pelvic x-ray with different views, as well as a pelvic CT scan. We proceeded by the same installation for all our patients (fig 01) in a dorsal decubitus position, on an orthopedic table and under radiographic control, based on the incidences (inlet and outlet of Penal) and profile incidence (known as Routt incidence) $[2,3]$.

For osteosynthesis, we used a specific ancillary including grooved screws, a grooved screwdriver, a $2 \mathrm{~mm}$ pin for finding the path, a grooved bit and a polyaxial screwdriver allowing the insertion of the screws in the cavity. To monitor the progress of okur patients, we opted for a clinical radio check at 4 weeks then at 3,6 and 12 months with evaluation of the final results based on the functional score of Majeed. We discuss the postoperative results as well as the resulting medical and technical considerations.

\section{RESULTS}

These were 10 young patients with an average age of 33 years (range 28 to 42 years), with high predominance of men (Sex Ratio: 4). The predominant mechanism was a road accident for 06 patients, a fall from a high height for 04 patients (including one case of attempted suicide). 07 patients were received in a context of polytrauma and underwent a detailed clinical examination followed by imaging studies based on the lesion assessment. 04 patients were admitted to the intensive care unit, including one patient who presented a medium-abundance pneumothorax drained immediately, and another patient presented a dislocated hip fracture (fracture of the posterior wall of the acetabulum treated surgically by a screwed plate). One patient presented with Faringer Stage III skin abrasion (fig 05). We didn't note any vascular nerve damage.

The time between admission and surgery is on average 03 days. All the patients underwent sacroiliac 
screw tightening with a single screw. The immediate post-operative consequences were simple. The followup is between 8 months and 30 months with an average follow-up of 12 months. The half-seated position at about $45^{\circ}$ was allowed for 45 days, then a gradual loading in the pool was maintained. Homo-or contralateral monopodal restraint is not authorized before a period of 03 months. According to the functional score of Majeed, we had good results in 08 of our patients, excellent for 01 patient and fair in 01 patient at 01 year follow-up.
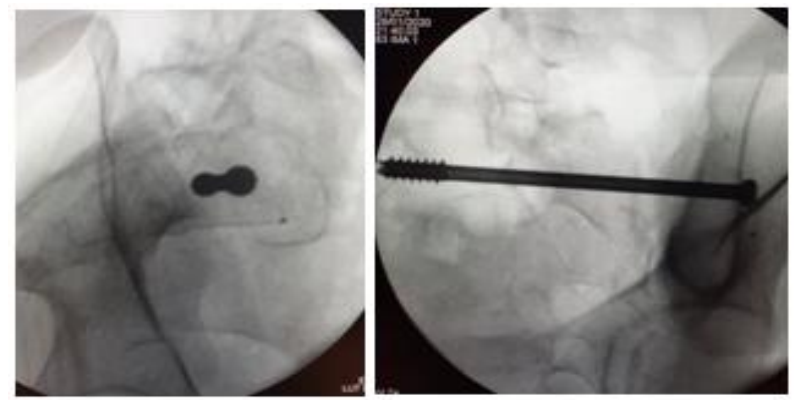

Fig-01: Decubitus Dorsal installation and marking in
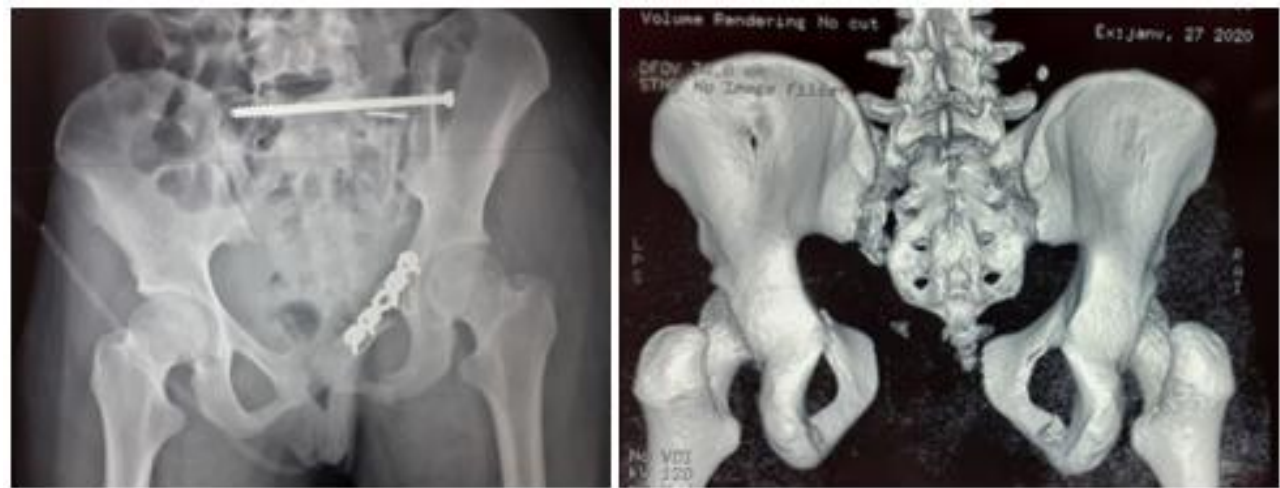

Fig-03: Imaging of a multiple trauma patient having suffered a stroke: left hip dislocation fracture with fracture of the lower end of the radius: preoperative 3D CT (a) recostruction, and postoperative $x$-ray of the pelvis (sacroiliac screwing) and special acetabular plate on the left)

\begin{tabular}{|c|c|c|}
\hline $\begin{array}{l}\text { Type A : Fractures ne touchant pas } \\
\text { l'anneau pelvien }\end{array}$ & Type B : Instabilité rotatoire & Type C : Instabilité verticale \\
\hline A1 : fractures avulsions & B1 : lésion unilatérale & $\begin{array}{l}\text { C1: la lésion verticale postérieure } \\
\text { est unilatérale }\end{array}$ \\
\hline A1 1. de l'épine iliaque antéro-supérieure & B1 1. disjonction symphysaire $<25 \mathrm{~mm}$ & $\begin{array}{l}\text { C1 1. le trait de fracture postérieur passe } \\
\text { dans l'aile iliaque }\end{array}$ \\
\hline A1 2. de l'épine iliaque antéro-inférieure & B1 2. disjonction symphysaire $>25 \mathrm{~mm}$ & $\begin{array}{l}\text { C1 2. le trait de fracture passe dans la } \\
\text { sacro-iliaque }\end{array}$ \\
\hline A1 3. de l’épine du pubis & & C1 3. le trait de fracture passe dans le sacrum \\
\hline A2 & B2 : unilatérale & $\begin{array}{l}\text { C2 : déplacement vertical d'un côté et } \\
\text { instabilité rotatoire de l'autre }\end{array}$ \\
\hline A2 1. fracture de la crête iliaque & $\begin{array}{l}\text { B2 1. les lésions antérieures et postérieures } \\
\text { sont homolatérales }\end{array}$ & C2 1 . le trait vertical passe en trans-iliaque \\
\hline $\begin{array}{l}\text { A2 2. fracture des } 2 \text { branches ilio-ishio- } \\
\text { pubiennes d'un cadre obturateur } \\
\text { A2 3. fracture des } 4 \text { branches ilio-ishio- } \\
\text { pubiennes }\end{array}$ & $\begin{array}{l}\text { B2 2. la lésion postérieure est controlatérale à } \\
\text { la lésion antérieure } \\
\text { B2 } 3 \text {. double lésion antérieure }\end{array}$ & $\begin{array}{l}\text { C2 2. le trait vertical passe en trans-sacro- } \\
\text { iliaque } \\
\text { C2 3. le trait vertical passe dans le sacrum }\end{array}$ \\
\hline A3 & B3 : bilatérale & C3 : ascension verticale des 2 hémi-bassins \\
\hline $\begin{array}{l}\text { A3 1. fractures du coccyx ou disjonction } \\
\text { sacro-coccygienne }\end{array}$ & B3 1. ouverture des 2 hémi-bassins & C3 1. les 2 traits verticaux sont extra-sacrés \\
\hline $\begin{array}{l}\text { A3 2. fractures transverses du sacrum non } \\
\text { déplacées }\end{array}$ & $\begin{array}{l}\text { B3 2. fermeture d'un côté et ouverture de } \\
\text { l'autre }\end{array}$ & $\begin{array}{l}\text { C3 2. un trait vertical est extra-sacré, l'autre } \\
\text { intra-sacré }\end{array}$ \\
\hline A3 3. fractures transverses du sacrum déplacées & B3 3. fermeture des 2 hémi-bassins & C3 3. les 2 traits verticaux sont trans-sacrés \\
\hline
\end{tabular}

Fig-4: Tile classification modified by AO
As complications, residual pain was noted in two patients, lameness was observed in one patient. All of our patients have returned to work. We noted no cases of vicious callus, non-union, or thromboembolic complications.

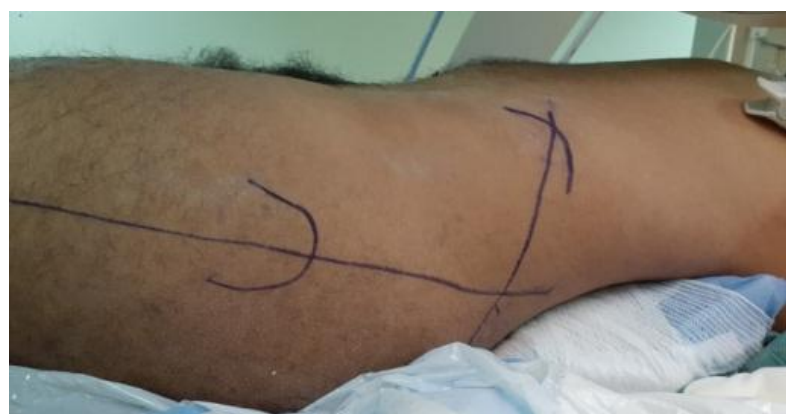

Fig-02: fluoroscopic control of the splined screw on an incidence point of introduction of the guide pin. front (a) and profile (b) 


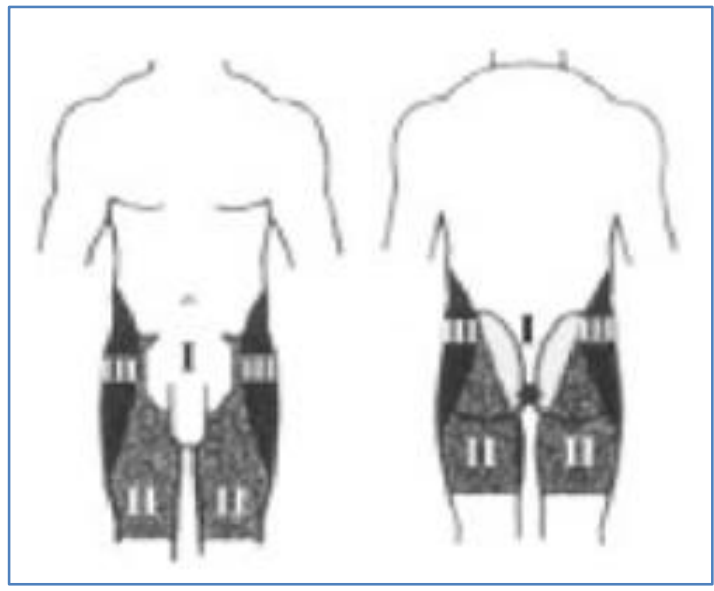

Fig-5: Faringer Classification

Zone I: perineum, anterior pubis, medial buttock, posterior sacrum

Zone II: medial thigh, groin crease

Zone III: posterolateral buttock, iliac crest

\section{DISCUSSION}

Fractures of the pelvis are vital emergencies when they cause instability of the pelvic ring. They are inherent to the mobility of individuals imposed by socio-professional activity. Unstable fractures pose hemodynamic problems when accompanied by vascular and visceral damage. [4] The management of these fractures has traditionally been conservative due to the anticipated difficulties of invasive surgery and a focus on initial patient survival [5].

Conventional surgical treatment of unstable pelvic fractures is very invasive and poses difficulties in reduction and retention. The problem with open surgery is to fix the iliac bone to the sacrum while avoiding muscle breakdown and blood loss. The advent of interventional radiology and in particular of the interventional scanner has made it possible, through micro-incisions, to position screws through the iliac bone and the sacrum by very precise guidance ensuring satisfactory stabilization without muscle breakdown.

The emergency external fixation by the Hoffman fixator, the installation of shockproof pants or a pelvic clamp and more simply a trans-osseous traction allow in these cases to compress the pelvis and or to stabilize the clots thus making it possible to cross the course the initial emergency, then proceed with the necessary explorations [6].

The principle of screwing is to connect the hip bone and the $\mathrm{S} 1$ vertebral body by a screw, that is to say to establish a rectilinear trajectory. The external table of the coxal bone, the spongy tissue of the iliac wing, the sacroiliac joint with the bone of the 2 coxal and sacral articular surfaces, the corridor of the sacral fin with fatty content, will be successively transfixed. the vertebral body of S1 made up of dense cancellous bone. The criteria for successful screwing are strictly intraosseous implantation controlled on CT cross sections along the axis of the screw. The value of this percutaneous technique has been well described in the literature with in particular a marked reduction in blood loss and the risk of infection [7].

This procedure requires knowledge of the anatomy of the lumbosacral osteo-ligamentous hinge and its vasculo-nervous relationships. The ability for three-dimensional spotting from two-dimensional fluoroscopic images can be developed using virtual computer tools [8].

\begin{tabular}{|c|c|c|c|}
\hline \multicolumn{4}{|c|}{ SCORE DE MANEED } \\
\hline \multicolumn{2}{|l|}{ DOULEUR: } & \multicolumn{2}{|l|}{ TRAVAIL: } \\
\hline - Intense, continue au repos & $0-5$ & . Pas de travail régulier & $0-4$ \\
\hline - Intense aux activités & 10 & - Travail léger & 8 \\
\hline - Tolérable mais limite les activités & 15 & - Changement de travail & 12 \\
\hline - Aux activités modérées, abolie au repos & 20 & - Même travail, performances réduites & 16 \\
\hline - Faible, intermittente, activités normales & 25 & - Même travail, mêmes performances & 20 \\
\hline - Minime, occasionnel ou pas de douleur & & & \\
\hline \multicolumn{2}{|l|}{ POSMON ASSISE : } & \multicolumn{2}{|l|}{ RAPPORTS SEXUES : } \\
\hline - Douloureuse & $0-4$ & . Douloureux & \\
\hline - Douloureuse si prolongée & 6 & - Douloureux si prolongés & 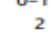 \\
\hline - Inconfortable & 8 & - Inconfortables & 3 \\
\hline - Libre & 10 & - Libres & 4 \\
\hline \multicolumn{2}{|l|}{$\begin{array}{l}\text { POSTION DEBOUT : } \\
\text { ADEALA MARCHE: }\end{array}$} & \multicolumn{2}{|l|}{$\begin{array}{l}\text { POSTMON DEBOUT : } \\
\text { DEMARCHE SANS ADE: }\end{array}$} \\
\hline - Alite la plupart du temps & $0-2$ & - Ne peut pas marcher & $0-2$ \\
\hline - Chaise roulante & 4 & - Quelques pas & 4 \\
\hline - 2 béquilles & 6 & - Boiterie importante & 6 \\
\hline - 2 cannes & 8 & - Boiterie modérée & 8 \\
\hline - 1 canne & 10 & - Boiterie légère & 10 \\
\hline - Sans canne & 12 & - Normal & 12 \\
\hline \multicolumn{4}{|l|}{$\begin{array}{l}\text { POSTION DEBOUT } \\
\text { DISTANCE DE MARCHE }\end{array}$} \\
\hline - Alite ou quelques mètres & $0-2$ & & \\
\hline - Temps et durée très limites & 4 & & \\
\hline - Limite avec des cannes, difficiles sans & 6 & & \\
\hline : 1 heure avec canne, limité sans & 8 & & \\
\hline $\begin{array}{l}\text { - } 1 \text { heure sans canne, } \\
\text { douleur légère ou boiterie }\end{array}$ & & & \\
\hline - Normal pour Páqc ct l'état général & 12 & & \\
\hline
\end{tabular}




\section{MAJEED SCORE}

\section{Majeed score}

Majeed score : out of 100 points : classifying the functional and social results at: Excellent $>85$; Good (70-84) ; average (55-69) ; bad $<55$

\section{CONCLUSION}

In conclusion, percutaneous sacroiliac screwing of pelvic ring trauma seems to us a minimally invasive technique, practicable whenever circumstances allow, especially since these lesions occur in a context of multiple trauma sometimes with other lesions. which can be life-threatening.

\section{REFERENCE}

1. Guifo ML, Farikou I, Pisoh CT, Ndoumbé A, Emaleu SB, Takongmo S. Visage sacro-iliaque percutané pour fracture instable du bassin de type C 1-2: à propos d'un cas au CHU de Yaoundé. The Pan African Medical Journal. 2014;19.

2. Giannoudis PV, Papadokostakis G, Alpantaki K, Kontakis G, Chalidis B. Is the lateral sacral fluoroscopic view essential for accurate percutaneous sacroiliac screw insertion? An experimental study. Injury. 2008 Aug;39(8):87580.
3. Percutaneous sacroiliac screw for unstable type C 1-2 hip bone fracture: about a case at the University Hospital of Yaounde3 - Vissage ilio-sacré percutané. Technique fluoroscopique - J. Tonetti , J. van Overschelde, B. Sadok, H. Vouaillat, A. Eid emc; 2013

4. Langford JR, Burgess AR, Liporace FR, Haidukewych GJ. Pelvic fractures: Part 1 Evaluation, classification, and resuscitation. Journal of the American Academy of Orthopaedic Surgeons. 2013 Aug;21(8):448-457.

5. Tonetti J, Thony F, Brun J, Arvieux C, Rancurel E, Guillet S. Stabilisation en urgence et fixation différée des traumatismes graves du bassin: expérience de Grenoble à propos de 120 patients opérés. E-memoires de l'Académie Nationale de Chirurgie. 2009;8(2):25-29.

6. Routt ML, Jr, Kregor PJ, Simonian PT, Mayo KA. Early results of percutaneous iliosacral screws placed with the patient in the supine position. $\mathrm{J}$ Orthop Trauma. 1995;9(3):207-14.

7. Routt ML, Jr, Simonian PT. Closedreduction and percutaneousskeletal fixation of sacral fractures. Clin Orthop. 1996;(329):121-8.

8. Mendel T, Noser H, Wohlrab D, Stock K, Radetzki F. The lateral sacral Triangle - A Decision Support for secure transverse sacroiliac Screw Insertion. Injury. 2011;42(10):1164-1170. 